\title{
MANAJEMEN PEMBIAYAAN DALAM MENINGKATKAN MUTU PENDIDIKAN DI UNIVERSITAS DEHASEN BENGKULU
}

\author{
Suwarni \\ Universitas Dehasen Bengkulu
}

\begin{abstract}
ABSTRAK
Suwarni; Tujuan penelitian ini adalah untuk mengetahui secara objektif dan mendalam tentang kebijakan dan implementasi manajemen keuangannya khususnya pembiayaan dalam kaitannya dengan peningkatan mutu pendidikan. Metode penelitian yang digunakan dalam penelitian ini adalah metode penelitian deskriptif yaitu suatu metode dalam meneliti status kelompok manusia, satu objek, satu kondisi, dengan satu sistem pemikiran atau satu kelas peristiwa pada masa sekarang. Hasil yang dicapai dalam mutu pendidikan dalam Universitas Dehasen Bengkulu, walau dalam pelaksanaan pembiayaan belum berjalan secara maksimal, bukan berarti tidak memiliki hasil yang baik. Adapun hasil yang dicapai diantarnya; kompetensi lulusan sangat mendukung dalam dunia kerja, memiliki etos kerja yang baik, dan memiliki motivasi yang tinggi untuk melanjutkan pendidikan ke jenjang yang lebih tinggi.
\end{abstract}

\section{ABSTRACT}

Suwarni; The purpose of this study was to determine objectively and depth of policy and implementation of financial management in particular in relation to the financing of education quality improvement. The method used in this research is descriptive research method is a method in researching the status of groups of people, one object, one condition, with a system of thought or one class of events in the present. The results achieved in the quality of education in the University Dehasen Bengkulu, although the implementation of the financing has not run optimally, does not mean not having good results. The delivery of the results achieved; competence of graduates is very supportive in the world of work, have a good work ethic, and have a high motivation to continue their education to a higher level.

Key words: Financial Management, Quality Of Education

\section{PENDAHULUAN}

Merujuk pada Undang-undang Nomor 20 Tahun 2003 tentang Sistem Pendidikan Nasional, Perguruan Tinggi (PT) dapat berbentuk akademi, politeknik, sekolah tinggi, institut dan universitas. Dari Evaluasi Program Studi Berbasis Evaluasi Diri Tahun 2011 dapat dilihat dalam tabel 1. yaitu:

Tabel 1. Evaluasi Program Studi Berbasis Evaluasi Diri Tahun 2011

\begin{tabular}{|c|c|c|c|c|c|}
\hline Data & PTN & $\%$ & PTS & $\%$ & Jumlah \\
\hline Perguruan Tinggi & 93 & $3 \%$ & 3.068 & $97 \%$ & 3.161 \\
\hline Mahasiswa & 907.323 & $9 \%$ & 2.200 .000 & $71 \%$ & 3.107 .323 \\
\hline Dosen & 151.642 & $5 \%$ & 122.092 & $45 \%$ & 273.734 \\
\hline Program Studi & 4.721 & $8 \%$ & 12.056 & $72 \%$ & 16.777 \\
\hline
\end{tabular}

Sumber : http://print.kompas.com/KOMPAS 2 Juni 2014:1

Dari tabel 1. data menunjukkan sebanyak 3.161 perguruan tinggi yang ada di Indonesia. Sebanyak 3.068 PTS atau 97 persen merupakan PTS, sedangkan PTN hanya berjumlah 93 atau 3 
persen. Jumlah mahasiswa PTS sekitar 2,2 juta orang atau sebesar 71 persen, sedangkan mahasiswa PTN hanya 907.323 orang atau 29 persen. Adapun jumlah dosen PTS sekitar 122.092 orang atau 45 persen dan jumlah dosen PTN sekitar 151.642 orang atau 55 persen dari jumlah keseluruhan dosen di Indonesia sebanyak 273.734 orang.

Hingga akhir 2012 tercatat sebanyak 16.777 program studi, yang terdiri dari 4.721 program studi di PTN dan 12.056 program studi di PTS yang ada di Indonesia. Akreditasi program studi yang masih berlaku terdata sebanyak 8.638. Selebihnya kedaluwarsa dan belum diakreditasi, baik yang sedang dalam proses pengajuan akreditasi di BAN-PT maupun yang belum diajukan. Akreditasi institusi berbeda dengan akreditasi program studi. Akreditasi institusi itu berarti akreditasi lembaganya secara keseluruhan. Akreditasi institusi dilakukan empat tahun sekali dan hingga kini baru beberapa perguruan tinggi negeri/swasta saja yang telah melakukan akreditasi institusi.

Kondisi Perguruan Tinggi (PT) pada saat ini dapat dilihat dari masih rendahnya kemampuan PT Indonesia dalam menghasilkan output sumber daya manusia yang berkualitas berawal pada kondisi PT yang tidak memiliki kemampuan dalam menyusun kurikulum pendidikan yang sesuai dengan kebutuhan pasar. Selain itu, peran pemerintah dalam mengeluarkan kebijakan yang terintegrasi untuk terciptanya link and match antara PT dengan dunia usaha belum sepenuhnya dijalankan. Hal ini dapat dilihat dari Data Ditjen Dikti Depdiknas dan dilaporkan Kompas, 6 Februari 2008 (Riduwan, 2010 : 23) menjelaskan bahwa jumlah sarjana menganggur melonjak drastis dari 183.629 orang pada tahun 2006 menjadi 409.890 pada tahun 2007, ditambah dengan pemegang gelar diploma I, II dan III yang menganggur berdasarkan pendataan tahun 2007 lebih dari 740.000 orang. Kondisi ini jelas telah terjadi ketidak sesuaian (mismatch) antara lulusan PT dan kualifikasi yang dibutuhkan sektor industri dan jasa di masyarakat, akibatnya timbul masalah ketika lulusan PT tersebut ingin mencari pekerjaan.

Sedangkan dari hasil survey Webometric tentang pemeringkatan perguruan tinggi dunia tahun 2014 (http://www.webometrics.info 23 Mei 2014:1) menyatakan 10 besar perguruan tinggi asal Indonesia yang meraih skor terbaik tingkat dunia dan tingkat ASEAN dapat dilihat dalam tabel di bawah ini :

Tabel 2. Rangking Perguruan Tinggi Indonesia Tingkat Dunia dan ASEAN Tahun 2014

\begin{tabular}{|l|l|c|c|}
\hline No & \multicolumn{1}{|c|}{ Perguruan Tinggi } & Tingkat Dunia & Tingkat ASEAN \\
\hline 1 & Universitas Gadjah Mada & 598 & 12 \\
\hline 2 & Institusi Teknologi Bandung & 636 & 16 \\
\hline 3 & Universitas Indonesia & 696 & 18 \\
\hline 4 & Universitas Air Langga & 1013 & 25 \\
\hline 5 & Universitas Padjajaran & 1036 & 26 \\
\hline 6 & Universitas Brawijaya & 1052 & 27 \\
\hline 7 & Universitas Diponegoro & 1088 & 29 \\
\hline 8 & Universitas Pertanian Bogor & 1156 & 32 \\
\hline 9 & Institut Teknologi Sepuluh November & 1228 & 34 \\
\hline 10 & Universitas Gunadarma & 1302 & 37 \\
\hline
\end{tabular}

Sumber : http://www.webometrics.info

Dari hasil survey tersebut di atas ternyata PT Indonesia dalam peringkat dunia tidak termasuk dalam 100 besar sedangkan pada tingkat ASEAN belum masuk kategori lima besar, hal ini sangat mengejutkan karena perguruan tinggi Indonesia dianggap kualitas dan kinerjanya tergolong masih rendah serta belum memiliki daya saing dengan perguruan tinggi negaranegara lain baik pada tingkat ASEAN maupun tingkat dunia. Dalam sepuluh besar di Indonesia ini terlihat bahwa di dominasi oleh PTN dan mulai tahun 2014 Universitas Gunadarma sebagai wakil PTS telah masuk kategori sepuluh besar Indonesia.

Lembaga Pendidikan Tinggi tidak akan mewujudkan visi dan misinya secara baik bilamana tidak menghiraukan aspek manajemen mutu, sebagaimana dikatakan Robert $\mathrm{N}$. Anthony menyatakan: 
"we shall refer to the person which is responsible for designing and operating the management control system as the controller. Actually, in many organization, the title of this is chief financial office". (1988: 106)

Oleh sebab itu, maka penyelenggaraan perguruan tinggi menuntut stategi pengelolaan keuangan yang dapat mengamankan penerimaan dan menggunakan dana untuk membiayai program secara ekomomis, efisien dan efektif serta menghasilkan akuntabilitas keuangan yang berkualitas. Pengelolaan keuangan menyangkut berbagai aktivitas yang berkaitan dengan perolehan dan penggunaan dana serta pemanfaatan surplus dari hasil pengelolaan dana tersebut.

Keuangan dan pembiayaan merupakan salah satu sumber daya yang secara langsung menjunjang efektifitas dan efisiensi pengelolaan pendidikan. Hal tersebut menuntut kemampuan untuk merencanakan, melaksanakan dan mengevaluasi serta mempertanggungjawabkan pengelolaan dana secara transparan kepada masyarakat dan pemerintah.

Dalam penyelenggaraan pendidikan, keuangan dan pembiayaan merupakan potensi yang sangat menentukan dan merupakan bagian yang tak terpisahkan dalam kajian manajemen pendidikan. Komponen keuangan dan pembiayaan pada suatu lembaga merupakan komponen produksi yang menentukan terlaksananya kegiatan lembaga bersama komponen-komponen yang lain. Dengan kata lain setiap kegiatan yang dilakukan memerlukan biaya, baik itu disadari maupun yang tidak disadari. Komponen keuangan dan pembiayaan ini perlu dikelola sebaikbaiknya, agar dana-dana yang ada dapat dimanfaatkan secara optimal untuk menunjang tercapainya tujuan pendidikan.

Dapat dipahami bahwa manajemen keuangan itu merupakan salah satu unsur yang penting dalam penyelenggaraan pendidikan, seperti halnya di Universitas Dehasen Bengkulu memiliki manajemen keuangan dan kebijakan yang berbeda.

Dengan demikian perguruan tinggi swasta khususnya Universitas Dehasen Bengkulu dapat meningkatkan mutu pendidikan. Dengan meningkatnya mutu pendidikan akan menciptakan sistem manajemen yang berkualitas, sehingga nantinya dapat menghasilkan pendidikan yang bermutu. Dari permasalahan di atas penulis sangat tertarik meneliti dengan judul Manajemen Pembiayaan Dalam Meningkatkan Mutu Pendidikan Di Universitas Dehasen Bengkulu.

\section{Landasan Teori Manajemen Pembiayaan Perguruan Tinggi}

Istilah manajemen memiliki banyak makna, di antaranya pengelolaan, ketatalaksanaan, kepemimpinan, pembinaan, pengurusan dan lain sebagainya. Untuk menghindari penafsiran yang berbeda-beda, maka penulis perlu menjelaskan pengertian secara komprehensif.

Manajemen berasal dari kata to manage yang artinya mengatur, pengaturan yang dilakukan melalui proses dan diatur berdasarkan urutan dan fungsi-fungsi manajemen itu. Jadi manajemen adalah suatu proses untuk mewujudkan tujuan yang diinginkan. Hasibuan (2006:1).

Manajemen adalah proses perencanaan, pengorganisasian, kepemimpinan dan pengendalian semua sumber daya organisasi untuk mencapai tujuan yang telah ditetapkan (Stonner, 2000: 5).

Menurut Daft (2010: 6) manajemen (management) adalah pencapaian tujuan-tujuan organisasional secara efektif dan efisien melalui perencanaan, pengolahan, kepemimpinan dan pengendalian sumber daya-sumber daya organisasional.

Kemudian Koontz \& O'Donnel, (1989: 3), mengemukakan bahwa: "Management is getting things done through people bringing about this coordinating of group activity the manager, as a manager, plans, organizes, staff, directs and controls the activities of other people". Maksud dari pendapat tersebut di atas adalah bahwa manajemen merupakan usaha organisasi untuk mencapai suatu tujuan tertentu melalui kegiatan antara anggota organisasi. Kondisi tersebut dapat dicapai melalui perencanaan, pengorganisasian, penempatan, pengarahan dan pengendalian. 
Hersey dan Blanchard (1988:4) sebagaimana dikutip oleh Syarifudin (2005:41) manajemen adalah proses bekerja sama antara individu dan kelompok serta sumber daya yang lainnya dalam mencapai tujuan organisasi sebagai aktivitas manajemen. Sedangkan menurut Terry (2009:1) manajemen adalah suatu proses atau kerangka kerja yang melibatkan bimbingan atau pengarahan suatu kelompok orang-orang ke arah tujuan-tujuan organisasional atau maksud-maksud yang nyata.

Dari beberapa definisi di atas, dapat penulis simpulkan bahwa manajemen adalah proses pengelolaan terhadap sumber daya yang dimiliki baik berupa sumber daya insani maupun sumber daya yang berupa potensi-potensi yang dimiliki guna mencapai tujuan yang telah direncanakan

Pengaturan biaya pendidikan di perguruan tinggi (PT) salah satunya adalah perguruan tinggi berkaitan dengan insentif dan tingkah laku kelembagaan PT untuk menghasilkan banyaknya kegiatan dari tahun ke tahun. Menurut R. Bowen (1970) dapat diasumsikan mengenai pengaturan-pengaturan biaya pada PT sebagai berikut:

1) Tujuan kelembagaan yang ideal adalah pendidikan yang excellence prestige dan bersikap influence. Yang dimaksud excellence atau disebut Quality suatu kelembagaan ditentukan dengan kriteria sebagai berikut : rasio karyawan dengan mahasiswa, penghasilan karyawan, jumlah doktor pada fakultas, jumlah buku di perpustakaan, fasilitas peralatan yang memadai dan kualifikasi mahasiswa di PT tersebut. Kriteria-kriteria ini adalah input untuk menghasilkan unit cost dalam bentuk uang, dalam hal ini bukan sebagai outcome dari proses pendidikan.

2) Yang dinamakan excellence prestige dan Influence adalah tidak adanya batasan terhadap jumlah uang suatu lembaga yang bisa dimanfaatkan bagi lajunya pendidikan.

3) Setiap kelembagaan meningkatkan keseluruhan keuangan yang ia dapatkan.

4) Tidak ada PT yang pernah mengakui mempunyai cukup uang dan semuanya mencoba untuk meningkatkan sumber dana tanpa batas.

5) Setiap lembaga menghasilkan sumber dana tanpa batas.

6) Secara kumulatif, keempat pengaturan tertuju pada peningkatan biaya pengeluaran.

Setiap perguruan tinggi perlu menyusun Rencana Anggaran Perbelanjaan Biaya Perguruan Tinggi (RAPBPT). Dalam menyusun rencana anggaran perbelanjaan maka harus diketahui lebih dahulu budget yang tersedia. Budget (rencana) adalah (1) rencana operasional keuangan mencakup estimasi tentang pengeluaran untuk suatu periode/kurun waktu; (2) rencana sistematis untuk efisiensi pemanfaatan tenaga, industry (sumber) dan (3) rencana keuangan yang diprioritaskan pada pola pengawasan operasional pada masa datang suatu lembaga. Aspek fungsional budget menggambarkan kegunaan atau manfaat dari budget adalah : (1) berpengaruh terhadap motivasi; (2) memungkinkan adanya koordinasi kerja; (3) dapat digunakan untuk kegiatan koreksi/bila terjadi penyimpangan; (4) meningkatkan alokasi sumber; (5) meningkatkan komunikasi; dan (6) sebagai alat evaluasi atau pengawasan.

\section{Mutu Pendidikan Tinggi}

Mutu memiliki macam-macam criteria, dan kriteria tersebut berubah secara terusmenerus. Orang berbeda memiliki kriteria yang berbeda pula. Untuk mendapatkan pemahaman tentang mutu pendidikan, berikut dikutip berbagai pengertian mutu dari berbagai sumber. Mutu dalam bahasa Indonesia disebut kualitas. Kualitas berasal dari bahasa Inggris quality. Quality dalam berbagai kamus mempunyai arti, tiga diantaranya (1) suatu sifat atau atribut yang khas dan membuat berbeda, (2) standar tertinggi sifat kebaikan dan (3) memiliki sifat kebaikan tertinggi (Tampubolon, 2001:106). Dalam kamus besar bahasa Indonesia, "mutu atau kualitas diartikan (ukuran) baik buruk suatu benda, kadar, taraf atau derajad (KUBI, 2003:667)."

Mutu adalah sesuatu yang dinamis mengikuti dinamika pelanggan dan lingkungan "Quality is a dynamic state associated with products, services, people, processes, and environments that meets or exceeds expectations" (Goetsch and Davis, 2006: 5). 
Dalam bidang pendidikan, mutu berkenaan dengan program dan hasil pendidikan yang dapat memenuhi harapan sesuai tingkat dan perkembangan masyarakat dalam dunia kerja. Dosen berusaha memberikan layanan pembelajarannya yang memberikan kepuasan kepada para mahasiswanya. Pimpinan lembaga pendidikan memberikan kepuasan kepada para dosen dan tenaga pendidikan lainnya, dan dalam kinerja kelembagaan secara keseluruhan memberikan kepuasan kepada masyarakat dan dunia kerja.

Mutu institusi perguruan tinggi merupakan totalitas keadaan dan karakteristik masukan, proses dan produk atau layanan institusi perguruan tinggi yang diukur dari sejumlah standar sebagai tolok ukur penilaian untuk menentukan dan mencerminkan mutu institusi perguruan tinggi.

Penilaian mutu dalam rangka akreditasi institusi perguruan tinggi harus dilandasi oleh standar yang lengkap dan jelas sebagai tolok ukur penilaian tersebut, dan juga memerlukan penjelasan operasional mengenai prosedur dan langkah-langkah yang ditempuh, sehingga penilaian itu dapat dilakukan secara sistemik dan sistematis.

\section{Konsep Mutu Program Pendidikan dan Pengajaran Program}

Program merupakan acuan kegiatan yang disusun dan dilaksanakan oleh suatu lembaga. Oleh karena itu, lembaga yang diberikan kepercayaan melaksanakan program selalu berhatihati dalam melaksanakannya, sehingga tidak terjadi ketimpangan. Menurut Joan L. Herman (Farida, 2000:9) "program ialah segala sesuatu yang coba dilakukan seseorang dengan harapan akan mendatangkan hasil atau pengaruh." Sedangkan menurut Suharsimi Arikunto (2005:291) "program adalah kegiatan yang direncanakan secara seksama." Bisa kita simpulkan bahwa program merupakan kumpulan kegiatan-kegiatan nyata, sistematis, dan terpadu yang dilakukan oleh perorangan, satu instansi, beberapa instansi, atau pun dalam rangka kerja sama masyarakat atau yang merupakan pastisipasi aktif masyarakat guna mencapai sasaran dan tujuan yang telah ditetapkan.

Itu berarti, pelaksanaan program atau aktivitas merupakan segala sesuatu yang harus dilakukan oleh instansi pemerintah atau lembaga non pemerintah dalam rangka merealisasikan program kerja operasionalnya. Aktivitas merupakan cerminan strategi kongkret organisasi untuk diimplementasikan dengan sebaik-baiknya dalam rangka mencapai tujuan dan sasaran. Aktivitas menjadi jantung keseharian organisasi dan menjadikan organisasi tetap hidup. Tanpa penentuan aktivitas yang jelas akan mengakibatkan banyak tenaga yang tidak terpakai.

Dalam konteks pelaksanaan program, kriteria yang dimaksud adalah kriteria keberhasilan pelaksanaan program dan hal yang dapat dinilai, dapat berupa dampak atau hasil yang dicapai atau prosesnya itu sendiri. Ada beberapa konsep yang terkandung dalam pernyataan ini, yaitu efektivitas yang merupakan rasio antara input-nya dan konsep efisien yang merupakan taraf pendayagunaan input untuk menghasilkan out put melalui suatu proses.

\section{Mutu}

Kata kualiatas memiliki banyak definisi yang berbeda, bervariasi dari konvensional sampai yang lebih strategik. Difinisi konvensional dari kualitas biasanya menggambarkan karakteristik langsung dari suatu produk seperti: kinerja (performance), keandalan (reliability), kemudahan dalam penggunaan (ease of use), estetika (esthetics), dan sebagainya. Bagaimanapun para manajer dari perusahaan yang sedang berkompetensi dalam pasar global harus memberikan perhatian serius pada definisi kualitas yang bersifat strategik, yaitu: kualitas adalah segala sesuatu yang mampu memenuhi kebutuhan pelanggan (meeting the needs of customers) (Gaspersz, 2011; 6).

Dalam quality vocabulary, kualitas didefinisikan sebagai totalitas dari karekteristik suatu produk yang menunjang kemampuannya untuk memuaskan yang dispesifikasikan atau 
ditetapkan. Kualitas sering diartikan sebagai kepuasan pelanggan (customer satsfication) atau kesesuaian terhadap kebutuhan atau persyaratan (conformance to the requirements).

American Society for Quality mendifinisikan kualitas (quality) adalah keseluruhan fitur dan dan karakteristik produk atau jasa yang mampu memuaskan kebutuhan yang tampak atau samar (Haizer, 2011:301).

Berdasarkan difinisi tentang kualitas baik yang konvensional maupun yang lebih strategik, kita boleh menyatakan bahwa pada dasarnya kualitas mengacu kepada pengertian pokok berikut:

1. Kualitas terdiri dari sejumlah keistimewaan produk baik keistimewaan langsung maupun keistimewaan atraktif yang memenuhi keinginan pelanggan dan dengan demikian memberikan kepuasan atas penggunaan produk itu.

2. Kualitas terdiri dari segala sesuatu yang bebas dari kekurangan atau kerusakan.

3. Pada dasarnya manajemen kualitas (Quality Management) atau manajemen kualitas terpadu (Total Quality Manajemen = TQM) didefinisikan sebagai suatu cara meningkatkan kineja secara terus menerus (continuously performance improvement) pada setiap lavel operasi atau proses, dalam setiap area fungsional dari suatu organisasi, menggunakan sumber daya manusia dan modal yang tersedia.

4. Manajemen mutu total (Total Quality Manajemen) merupakan upaya yang dilakukan oleh seluruh perusahaan untuk terus memperbaikicara-cara manusia, mesin dan sistem dalam melakukan pekerjaan (Raymon A. Noe et al., 2007:36).

5. Quality Vocabulary (ISO 9001:2005) mendifinisikan Manajemen Kualitas sebagai semua aktivitas dari fungsi manajemen secara keseluruhan yang menentukan kebijakan kualitas, tujuan-tujuan dan tanggung jawab, serta mengimplementasikannya melalui alat-alat seperti perencanaan kualitas (quality planning), pengemdalian kualitas (quality control), jaminan kualitas (quality assurance) dan peningkatan kualitas (quality improvement). Tanggung jawab untuk manajemen kualitas ada pada semua lavel dari manajemen, tetapi harus dikendalikan oleh manajemen puncak (top Manajemen), dan implementasinya harus melibatkan semua anggota organisasi.

6. Manajemen kualitas dari pengertian tersebut pada dasarnya berfokus pada perbaikan terus menerus untuk memenuhi kebutuhan pelanggan. Dengan demikian manajemen kualitas berorentasi pada proses yang mengintregasikan semua sumber daya manusia, pemasokpemasok (suppliers), dan pelanggan-pelanggan (customers), di dalam lingkungan perusahaan (corporate environment). Hal ini berarti bahwa manajemen kualitas merupakan kemampuan atau kapabilitas yang melekat dalam sumber daya manusia serta merupakan proses yang dapat dikontrol (controllable process), bukan suatu kebetulan belaka.

Deming dalam Ali (2000: 27) meskipun mutu mencakup kesesuaian atribut produk dengan tuntutan konsumen, namun kualitas harus lebih dari itu. Menurut Deming terdapat empat belas poin penting yang dapat membawa atau membantu manajer mencapai perbaikan dalam mutu yaitu :

1) Menciptakan kepastian tujuan perbaikan produk dan jasa

2) Mengadopsi filosofi baru dimana cacat tidak bisa diterima

3) Berhenti tergantung pada inspeksi massal

4) Berhenti melaksanakan bisnis atas dasar harga saja

5) Tetap dan continue memperbaiki sistem produksi dan jasa

6) Melembagakan metode pelatihan kerja modern

7) Melembagakan kepemimpinan

8) Menghilangkan rintangan antar departemen

9) Hilangkan ketakutan

10) Hilangkan atau kurangi tujuan-tujuan jumlah pada pekerja

11) Hilangkan managemen berdasarkan sasaran

12) Hilangkan rintangan yang merendahkan pekerja jam-jaman

13) Melembagakan program pendidikan dan pelatihan yang cermat

14) Menciptakan struktur dalam manajemen puncak yang dapat melaksanakan transformasi seperti dalam poin-poin di atas. 
Dari definisi-definisi tersebut dapat disimpulkan bahwa mutu berkenaan dengan produk dan layanan, yang dapat memenuhi kebutuhan, harapan dan kepuasaan dari pelanggan. Mutu tidak bersifat sesaat tetapi dalam jangka panjang, dalam jangka tersebut mutu perlu terus diubah, ditingkatkan dan disempurnakan agar selalu dapat memenuhi kebutuhan dan memuaskan pelanggan dan sesuai dengan perkembangan lingkungan. Mutu merupakan suatu nilai yang tinggi yang sudah memenuhi standar atau melebihi standar atau keinginan pelanggan. Untuk mewujudkannya diperlukan proses yang panjang dan terencana.

\section{Sistem Penjaminan Mutu pada Perguruan Tinggi}

Dewasa ini akreditasi telah dilaksanakan baik pada jenjang pendidikan tinggi maupun pendidikan dasar dan memengah. Pada jenjang pendidikan tinggi pelaksanaannya lebih intensif. Secara berkala akreditasi, telah dilakukan baik terhadap perguruan tinggi negeri maupun swasta. Pada jenjang pendidikan dasar dan menengah, sekolah menengah kejurusan, penjaminan mutu telah berjalan lebih insentif, terkait dengan tugas menyiapkan tenaga kerja yang berkeahlian dalam menunjang keberhasilan industri. Adanya kebutuhan global mengenai produk industri yang berkualitas, mendorong sekolah menengah kejuruan untuk menyesuaikan diri sesuai dengan standar keahlian yang ditetapkan.

\section{Standar Mutu}

Secara umum yang dimaksud dengan penjaminan mutu adalah proses penetapan dan pemenuhan standar pengelolaan secara konsisten dan berkelanjutan sehingga pelanggan, produsen atau pemberi layanan dan pihak lain yang berkepentingan memperoleh kepuasan. Dengan demikian, penjaminan mutu perguruan tinggi adalah proses penetapan dan pemenuhan standar pengelolaan pendidikan tinggi secara konsisten dan berkelanjutan, sehingga stakeholders memperoleh kepuasan.

Untuk itu, Perguruan Tinggi (PT) memilih dan menetapkan sendiri standar pendidikan tinggi untuk setiap satuan pendidikan. Pemilihan dan penetapan standar itu dilakukan dalam sejumlah aspek yang disebut butir-butir mutu. Standar dibutuhkan oleh PT sebagai acuan dasar dalam rangka mewujudkan visi dan menjalankan misinya. Acuan dasar tersebut antara lain meliputi kriteria dan kriteria minimal dari berbagai aspek yang terkait dengan penyelenggaraan pendidikan tinggi. Selain itu, standar juga dimaksudkan memacu PT agar dapat meningkatkan kinerjanya dalam memberikan layanan yang bermutu dan sebagai perangkat untuk mendorong terwujudnya transparansi dan akuntabilitas publik dalam penyelenggaraan tugas pokoknya.

Standar mutu juga merupakan kompetensi/kualitas minimum yang dituntut dari lulusan/PT terkait, yang dapat diukur dan dapat diuraikan menjadi parameter dan indikator. Dalam siklus peningkatan mutu yang berkelanjutan, standar perlu dievaluasi dan direvisi/ditingkatkan melalui benchmarking secara berkelanjutan. Standar yang ditetapkan oleh pemerintah yang tercantum dalam Peraturan Pemerintah Nomor 19 tahun 2003 tentang Standar Nasional Pendidikan (SNP) diatur seminimal mungkin untuk memberikan keleluasan kepada masing-masing satuan pendidikan dan PT untuk mengembangkan mutu layanannya sesuai dengan program studi dan keahlian masing-masing.

Undang-Undang Nomor 20 Tahun 2003 tentang Sistem Pendidikan Nasional (Sisdiknas) Bab IX Pasal 35 dan PP No 19 Tahun 2005 tentang Standar Nasional Pendidikan (SNP) Bab II Pasal 2 hanya menetapkan 8 Komponen standar nasional pendidikan. Dalam pasal-pasalnya dinyatakan bahwa SNP disempurnakan secara terencana, terarah, dan berkelanjutan sesuai dengan tuntutan perubahan kehidupan lokal, nasional dan global. Berarti PT wajib menambah lingkup standar agar dapat meningkatkan kualitasnya dan meningkatkan daya saing bangsa.

\section{Metode Penelitian}

Metode penelitian yang digunakan dalam penelitian ini adalah metode deskriptif. Menurut Nazir (2007:125), "metode penelitian deskriptif adalah suatu metode dalam meneliti 
status kelompok manusia, satu objek, satu kondisi, dengan satu sistem pemikiran atau satu kelas peristiwa pada masa sekarang." Tujuan penelitian deskriptif adalah untuk membuat gambaran atau lukisan secara sistematis, aktual dan akurat mengenai fakta-fakta sifat, serta hubungan antara fenomena yang diselidiki.

\section{HASIL DAN PEMBAHASAN}

Sumberdaya dana/keuangan Unived berasal dari Yayasan, pemerintah, masyarakat dan/atau sumber lain sesuai dengan ketentuan, peraturan dan perundang-undangan yang berlaku.

\section{Perencanaan}

Perencanaan pembiayaan di UNIVED menggunakan beberapa tahapan, baik yang menjadi tradisi pada umumnya ataupun yang sudah terdokumentasikan. Untuk mutu penddikan tersebut melakukan beberapa langkah, yaitu (1) pembentukan tim, (2) pengumpulan data, (3) merumuskan Renstra, (4) pembahasan Renstra, dan (5) sosialisasi.

Substansi pada pasal 62 Peraturan Pemerintah No.32 tahun 2013 tentang Standar Nasional Pendidikan (SNP) kaitannya dengan Standar Pembiayaan pada setiap Perguruan Tinggi, mengatur dan menetapkan butir-butir mutu tentang komponen biaya pendidikan yang terdiri atas biaya investasi, biaya operasi, dan biaya personal. Secara khusus dinyatakan bahwa biaya investasi satuan pendidikan meliputi biaya penyediaan sarana dan prasarana, pengembangan sumberdaya manusia, dan modal kerja tetap. Biaya personal meliputi biaya pendidikan yang harus dikeluarkan oleh peserta didik untuk bisa mengikuti proses pembelajaran secara teratur dan berkelanjutan sedangkan biaya operasi satuan pendidikan meliputi gaji pendidik dan tenaga kependidikan. Dengan pertimbangan tersebut maka Universitas Dehasen Bengkulu dalam kaitannya dengan proses pembiayaan memerlukan standar pembiayaan dengan mengacu peraturan pemerintah dan peraturan perundangundangan khususnya yang mengatur tentang pembiayaan serta peraturan yang berlaku di Universitas Dehasen Bengkulu sebagai pedoman dan tolok ukur bagi semua unit kerja yang bertanggung jawab dalam perannya sebagai Pengguna Anggaran (PA) atau Kuasa Pengguna Anggaan (KPA) dan sebagai upaya memenuhi visi dan misi Universitas Dehasen Bengkulu sebagai Universitas yang terkemuka di Indonesia Standar mutu kegiatan pengelolaan keuangan disusun berdasarkan Rencana Anggaran Pendapatan dan Belanja (RAPB), dengan mengacu kepada sasaran yang ingin dicapai oleh setiap kegiatan.

Standar ditetapkan dengan mengacu visi dan misi Universitas Dehasen Bengkulu dan semua pihak yang terkait (stakeholder) dalam setiap sat-uan kegiatan dalam Tridarma Perguruan Tinggi. Universitas Dehasen Bengkulu merumuskan substansi standar sesuai dengan situasi lingkungan internal dan eksternal melalui analisis lingkungan strategis (Renstra dan Renop) sebagai bahan penyusunan RAPB/RKAT setiap kegiatan Tridarma Perguruan Tinggi. Standar arah kebijakan pengelolaan keuangan merupakan salah satu komponen yang sangat penting mewujudkan good governance harus mengacu pada unsur-unsur utama yaitu partisipatif, taat hukum, transparansi, efektif dan efisien serta akuntabilitas.

Berhubungan dengan anggaran pendapatan dan belanja universitas dehasen bengkulu diatur sebagai berikut:

1. Rektor merencanakan Anggaran Pendapatan dan Belanja Universitas yang disusun atas dasar prinsip anggaran berimbang.

2. Rektor menetapkan rencana penerimaan dan pembiayaan serta pengaturannya dengan mengikuti ketentuan pengelolaan dana yang berlaku, sesuai dengan azas efisiensi, akuntabilitas, otonomi, dan transparansi perguruan tinggi.

3. Rencana Anggaran Pendapatan dan Belanja Universitas setelah disahkan oleh Senat Universitas diajukan oleh Rektor kepada Yayasan untuk disahkan.

4. Yayasan berhak mengkaji dan mengadakan evaluasi usulan Rencana Anggaran Pendapatan dan Belanja Universitas. 
5. Anggaran Pendapatan dan Belanja Universitas, berlaku selama 1 (satu) tahun dari tanggal 1 (satu) September sampai dengan tanggal 31 Agustus tahun berikutnya.

Anggaran penerimaan belanja universitas dehasen bengkulu berupa penerimaan anggaran yang bersumber dari:

1. Pembayaran dari mahasiswa, yaitu pendapatan yang berasal dari kewajiban keuangan mahasiswa dalam rangka penyelenggaraan tri darma perguruan tinggi

2. Sumbangan, yaitu pendapatan yang berasal dari penyumbang termasuk beasiswa, baik dari yayasan Dehasen, dan Bank.

3. Jasa dan bunga, yaitu pendapatan dari jasa penelitian,jasa/bunga simpanan Giro di Bank

4. Penerimaan untuk pihak ke-3 yaitu penerimaan pajak untuk disetorkan kepada negara.

Program studi manajemen universitas dehasen bengkulu Perencanaan anggaran dilakukan oleh prodi melalui rapat dosen-dosen prodi, yang meliputi biaya-biaya insidental tingkat prodi seperti kegiatan praktikum, praktek lapangan, sarana, prasarana dan lain-lain. Prodi mengajukan rencana anggaran kebutuhan prodi yang diajukan kepada Dekan selaku pimpinan Fakultas untuk disahkan. Selanjutnya pimpinan fakultas mengajukan rencana anggaran bersama dengan prodi lain yang ada di Fakultas Ekonomi ke universitas untuk ditindaklanjuti/direalisasikan.

Tabel 3. Realisasi Penerimaan Dana Pada Program Studi Manajemen Universitas Dehasen Bengkulu

\begin{tabular}{|l|l|r|r|r|}
\hline \multirow{2}{*}{$\begin{array}{c}\text { Sumber } \\
\text { Dana }\end{array}$} & \multicolumn{2}{|c|}{ Jenis Dana } & \multicolumn{3}{c|}{ Jumlah Dana (Juta Rupiah) } \\
\cline { 3 - 5 }$(\mathbf{1})$ & \multicolumn{1}{c|}{$(\mathbf{2})$} & $\mathbf{2 0 1 1}$ & \multicolumn{1}{c|}{$\mathbf{2 0 1 2}$} & \multicolumn{1}{c|}{$\mathbf{( 3 )}$} \\
\hline PT sendiri & SPP & 1.324 .000 .000 & 1.919 .000 .000 & 2.412 .000 .000 \\
\hline & PKL & 26.000 .000 & 59.000 .000 & 61.000 .000 \\
\hline & Seminar & 31.000 .000 & 71.000 .000 & 73.000 .000 \\
\hline & Skripsi & 63.000 .000 & 143.000 .000 & 172.000 .000 \\
\hline & Yudisium dan Wisuda & 157.000 .000 & 358.000 .000 & 369.000 .000 \\
\hline Sumber lain & DPPKAD & & & 30.000 .000 \\
\hline Total & & $\mathbf{1 . 6 0 1 . 0 0 0 . 0 0 0}$ & $\mathbf{2 . 5 5 0 . 0 0 0 . 0 0 0}$ & $\mathbf{3 . 1 1 7 . 0 0 0 . 0 0 0}$ \\
\hline
\end{tabular}

Sumber: Universitas Dehasen Bengkulu, 2014

Dari tabel 3. dapat dlihat bahwa perkembangan penerimaan dana pada program studi manajemen universitas dehasen bengkulu semakin meningkat dari tahun ketahun.

\section{Pelaksanaan}

Setelah RAPB/RKAT disusun diperoleh jumlah anggaran yang diperlukan untuk membiayai seluruh kegiatan yang direncanakan sesuai dengan ketersediaan dana yang dapat dianggarkan untuk melaksanakan RAPB. Hal tersebut perlu dilakukan inventarisasi sumbersumber pemasukan keuangan beserta besaran dananya berupa donator, SPP mahasiswa, kontrak penelitian, kegiatan usaha, dana rutin pemerintah, pinjaman bank dan lain-lain

Pengalokasian dana berupa pengeluaran anggaran yang terdiri dari:

(1) Belanja pegawai, yaitu pengeluaran untuk memenuhi hak-hak perorangan pegawai sesuai dengan peraturan yang berlaku.

(2) Belanja barang, yaitu pengeluaran untuk pengadaan barang atau jasa tertentu termasuk investasi.

(3) Belanja pemeliharaan, yaitu pengeluaran untuk keperluan pemeliharaan materiil dan sarana prasarana.

(4) Belanja perjalanan, yaitu pengeluaran untuk mendukung pelaksanaan tugas/kegiatan ke luar daerah kedudukan unit organisasi. 
Universitas Dehasen Bengkulu menggunakan bentuk penganggaran pembukuan dimana semua penerimaan dan pengeluaran harus dibukukan terlebih dahulu kemudiannya uangnya diterima atau dibayarkan. Selain itu juga sistem keuangan di Universitas Dehasen Bengkulu sudah menggunakan sistem BANK dimana segala bentuk keuangan disimpan di BANK dan jika ada keperluan ataupun yang lainnya maka uang tersebut akan di ambil disana.

Dalam pelaksanaannya program studi manajemen Universitas Dehasen Bengkulu dalam penggunaan dana bisa dilihat pada tabel 4. berikut ini:

Tabel 4. Penggunaan dana pada Program Studi Manajemen Universitas Dehasen Bengkulu

\begin{tabular}{|c|c|c|c|c|}
\hline \multirow{2}{*}{ No. } & \multirow{2}{*}{ Jenis Penggunaan } & \multicolumn{3}{|c|}{ Persentase Dana } \\
\hline & & 2011 & 2012 & 2013 \\
\hline 1 & Pendidikan & 1.072 .670 .000 & 1.734 .000 .000 & 2.181 .900 .000 \\
\hline 2 & Penelitian & 208.130 .000 & 280.500 .000 & 311.700 .000 \\
\hline 3 & Pengabdian kepada Masyarakat & 176.110 .000 & 229.500 .000 & 218.190 .000 \\
\hline 4 & Investasi prasarana & - & 51.000 .000 & 31.170 .000 \\
\hline 5 & Investasi sarana & 144.090 .000 & 178.500 .000 & 218.190 .000 \\
\hline 6 & Investasi SDM & - & 76.500 .000 & 155.850 .000 \\
\hline 7 & Lain-lain & & & \\
\hline
\end{tabular}

Sumber: Universitas Dehasen Bengkulu, 2014

\section{Pengawasan dan Pertanggung Jawaban}

Pengawasan pembiayaan di Universitas Dehasen Bengkulu selalu dilakukan serta jika ada Revisi RAPB dapat dilakukan jika estimasi pemasukan keuangan dari sumber-sumber pendapatan yang sudah pasti ternyata jumlahnya lebih kecil dari anggaran untuk melaksanakan RAPB, dimungkinkan menciptakan sumber pemasukkan baru seperti mencari kontrak penelitian, kegiatan usaha, pinjaman bank yang baru atau kebijakan baru seperti melakukan investasi dengan pengembalian yang cepat dengan resiko kecil, menerapkan penghematan pengeluaran pembiayaan, menerapkan manajemen asset untuk menurunkan pemborosan.

Untuk menjamin efisiensi penggunaan anggaran dan menghindari kecurangan maka Universitas Dehasen Bengkulu melakukan audit internal. Audit internal dilakukan oleh Badan Penjaminan Mutu (BPM).

Monitoring dan Evaluasi (Monev) penggunaan anggaran dan keuangan dilakukan oleh: Kepala BPH Yayasan Dehasen Bengkulu dan Rektor Universitas Dehasen Bengkulu. Hasil Monev dinyatakan dalam bentuk berita acara, laporan, dan nota. Jika ditemukan penyimpanganpenyimpangan dalam pengelolaan dan pengurusan keuangan maka akan diambil tindakan sesuai dengan ketentuan peraturan yang berlaku.

Proses pertanggung jawaban pembiayaan di Universitas Dehasen Bengkulu dimana Rektor mempertanggung jawabkan Anggaran Pendapatan dan Belanja Universitas beserta pencapaian sasaran kegiatan kepada Yayasan dan pemerintah, sesuai dengan ketentuan, peraturan dan perundang-undangan yang berlaku. Serta Pertanggungan Jawab Rektor Universitas Dehasen Bengkulu seperti dimaksud tersebut, disusun dalam sebuah laporan lengkap pada setiap periode.

\section{Hasil}

Pengelolaan dana di Universitas Dehasen Bengkulu menganut azas efesiensi, efektivitas, produktivitas, terpadu, transparan dan dipertanggungjawabkan melalui prosedur sesuai peraturan yang berlaku. Pengelolaan pembiayaan di Universitas Dehasen Bengkulu Rektor hanya bertugas mengelola kegiatan pendidikan. laporan RAPBM dipertanggungjawabkan kepada Kepala BPH Yayasan Dehasen Bengkulu, Rektor juga bertugas pelaksana bagaimana meningkatkan mutu pendidikan yaitu dengan mengkoordinir kegiatankegiatan demi berlangsungnnya peningkatan mutu pendidikan melalui pembiayaan yang telah diatur oleh pembantu direktur bidang keuangan. 


\section{Faktor Pendukung dan Penghambat}

Faktor pendukung pembiayaan dalam meningkatkan mutu pendidikan di Universitas Dehasen Bengkulu adalah banyaknya mahasiswa yang diterima di Universitas Dehasen Bengkulu dimana memberikan masukan bagi pendanaan bagi universitas, disi lain adanya bantuan dari pemerintah berupa Hibah dan bantuan sertifikasi Dosen. Sealain itu respon positif dari pihak yayasan yang menyediakan sarana dan prasarana penunjang bagi kegiatan-kegiatan mahasiswa dan proses pembelajaran di Universitas Dehasen Bengkulu. Sarana prasarana merupakan bagian penting dalam menentukan kelancaran proses pembelajaran. Tanpa sarana dan prasarana yang cukup memadai proses pendidikan tidak akan berjalan dengan baik dan mempengaruhi peningkatan mutu pendidikan

Adapun faktor yang menghambat pembiayaan yang berada di Universitas Dehasen Bengkulu yaitu adanya kebijakan penerimaan pegawai negeri dan pernyetaraan pegawai negeri dengan akreditasi minimal B dimana mengakibatkan penurunan mahasiswa yang ingin kuliah di Universitas Dehasen Bengkulu sehingga banyak yang berpindah untuk mencari program studi yang memiliki akreditasi $\mathrm{B}$, dengan berkembangnya teknologi untuk biaya pemeliharaan sarana dan prasarana bisa lebih besar, menjadikan faktor penghambat pembiayaan.

\section{Kesimpulan}

Berdasarkan pembahasan tersebut di atas, maka dapat ditarik kesimpulan:

1. Perencanaan

Dalam proses merencanakan pembiayaan pada Universitas Dehasen Bengkulu melaksanakan dalam beberapa dimensi yaitu, 1) prarencana yang berisi: pengumpulan dan pengolahan data, diagnosis, perumusan kebijakan, estimasi kebutuhan, menganggarkan kebutuhan dan memilih sasaran, 2) merumuskan rencana, 3) perincian rencana, 4) implementasi rencana, dan 5) revisi dan perencanaan kembali. Proses perencanaan mencakup penentuan sasaran, penentuan strategi dan pengembangan rencana untuk mengatur kegiatan.

2. Pelaksanaan

Dalam pelaksanaannya pembiayaan terpenuhi dan terealisasi pada Universitas Dehasen Bengkulu dimana aspek penting dalam peningkatan mutu pendidikan dengan dibuktikan kepemilikan sarana dan prasarana yang memenuhi kegiatan mahasiswa dan dosen yang memenuhi kebutuhan perguruan tinggi.

3. Pengawasan dan Pertanggung jawaban

Pengawasan pembiayaan di Universitas Dehasen Bengkulu selalu dilakukan melaksanakan RAPB, dimungkinkan menciptakan sumber pemasukkan baru seperti mencari kontrak penelitian, kegiatan usaha, pinjaman bank yang baru atau kebijakan baru seperti melakukan investasi dengan pengembalian yang cepat dengan resiko kecil, menerapkan penghematan pengeluaran pembiayaan, menerapkan manajemen asset untuk menurunkan pemborosan. Adapun kegiatan manajemen pembiayaan di Universitas Dehasen Bengkulu berupa pemeriksaan terhadap penerimaan dan pertanggung jawaban keuangan kepada pengawas keuangan yayasan.

4. Hasil

Hasil yang dicapai dalam mutu pendidikan dalam Universitas Dehasen Bengkulu, walau dalam pelaksanaan pembiayaan belum berjalan secara maksimal, bukan berarti tidak memiliki hasil yang baik. Adapun hasil yang dicapai diantarnya; kompetensi lulusan sangat mendukung dalam dunia kerja para lulusan, para lulusan memiliki etos kerja yang baik, dan memiliki motivasi yang tinggi untuk melanjutkan pendidikan ke jenjang yang lebih tinggi.

5. Faktor pendukung dan Penghambat

Faktor pendukung proses peningkatan mutu pendidkan dalam Universitas Dehasen Bengkulu yaitu; adanya evaluasi proses perkuliahan, evaluasi yang baik terhadap kinerja dosen dalam kegiatan proses pembelajaran yang dilakukan setiap semester, adanya fasilitasi interaksi antar dosen di dalam kampus, interaksi antar dosen dilakukan secara 
formal maupun informal. Pimpinan menciptakan kerjasama dan hubungan yang baik dalam perguruan tinggi, suasana kerja yang kondusif serta menjalin komunikasi yang baik dengan bawahan sehingga, adanya keeratan hubungan antara satu dengan yang lainnya, antara atasan dengan bawahan ataupun antar sesama pegawai, dosen. Adapun hambatan yang dihadapi Universitas Dehasen Bengkulu antara lain; sumber daya yang belum optimal, sarana dan prasarana masih dalam proses pembenahan dan pengembangan, fasilitas masih terbatas dan pemanfaatannya masih belum maksimal, SDM yang ada belum seluruhnya mampu menggunakan fasilitas seperti jaringan IT dalam proses belajar mengajar, masih perlu pengembangan dan latihan operasional dalam pemanfaatan teknologi tersebut, sosialisasi belum menyeluruh dan masih bersifat verbal pada hal-hal teknis, yakni dalam bentuk dialog tentang peraturan dan kebijakan dan tata kerja belum jelas dan dipahami secara utuh oleh seluruh civitas akademika perguruan tinggi.

\section{Saran}

Saran yang dapat diberikan bagi Universitas Dehasen Bengkulu adalah sebagai berikut:

1. Pelaksanaan keuangan di Universitas Dehasen Bengkulu sebaiknya dengan sistem on-line dengan bank sehingga dalam proses pelaksanaan pembiayaan berjalan secara efektif sehingga prosesnya tidak bertahap dan tidak membutuhkan waktu yang lama. Dengan menggunakan sistem on-line akan membentuk suatau kepercayaan (trust) kepada masyrakat dan stakeholder bahwa transparansi keuangan sangat penting terutama usaha dalam meningkatkan mutu pendidikan melalui bidang-bidang pendidikan. memperhatikan tujuan organisasi dan memilih serangkaian aksi dari beberapa alternatif yang ada dan menentukan apa yang harus dilakukan, bagaimana, kapan dan siapa yang melakukan untuk mencapai tujuan tersebut, maka program akan terlaksana secara optimal.

2. Dengan keterbatasan sumber dana yang di perolehnya harus dapat memanfaatkan semaksimal mungkin untuk membiayaai dalam rangka meningkatkan mutu pendidikan di masing-masing universitas dan apabila keseluruhan proses kegiatan kemahasiswaan, peningkatan profesionalisme dosen serta sarana dan prasarana di perguruan tinggi di penuhi maka tujuan program peningkatan kompetensi lulusan perguruan tinggi akan berjalan secara efektif, efisien, produktif.

3. Menjadi modal strategi dan titik pijak peningkatan manajemen mutu pendidikan ke depan sesuai kekuatan dan kelemahan yang dimilikinya. Diharapkan dengan Akreditasi minimal B akan memberikan dampak yang positif bagi semuanya baik masyarakat maupun stakeholder.

\section{DAFTAR PUSTAKA}

Ali, M., (2000), Penjaminan Mutu dalam Manajemen Mutu Pendidikan. Jurnal Mimbar Pendidikan, Nomor 3 Tahun xxi.

Arikunto, S., (2002). Prosedur Penelitian: Suatu Pendekatan Praktek Kerja. Rineka Cipta : Jakarta

Bowen. R. Howard (1970), The Cost Of Higher Education, Jossey Bassem Publisher

Daft, R.L, (2010). Manajemen Edisi 6, Jakarta. PT. Salemba Empat

Farida Yusuf Tayibnapis. (2000). Evaluasi program. Jakarta: Rineka Cipta

Fatah, N., (2000), Ekonomi dan Pembiayaan Pendidikan, Bandung: Remaja Rosdakarya

Gaspersz, (2011), Total Quality Management Untuk Praktisi Bisnis Dan Industri, Vinchristo Publication, Bogor 
Goetsch, L. David \& Davis, Stanley B. (2006). Quality Management Introduction to Total Quality Management for Production. Proses and Services. Fifth Ed. New Jersey: Pearson International Edition.

Hasibuan, M.S.P, (2006), Manajemen Dasar, Pengertian, dan Masalah, Edisi Revisi, Jakarta: Bumi Aksara.

http://print.kompas.com/KOMPAS 2

http://www.webometrics.info

ISO. (2008). Internasional Standard ISO 9001:2008(E), Quality Management SystemRequirement.Geneva

Jay H., Barry R., (2011), Manajemen Operasi, buku 1, edisi 9, Salemba Empat, Jakarta

Kamus Umum Bahasa Indonesia, Edisi Ketiga, (2003), Balai Pustaka, Jakarta.

Koontz, H. \& O'Donnel, C. (1989). Principles, an Analisys of Managemen Function, New York, McGraw Hill bOok Company.

Nazir M., (2007). Metode Penelitian, Jakarta: Ghalia Indonesia.

Noe, R.A, et al., (2007), Manajemen Sumber Daya Manusia. Edisi Kesepuluh. Jakarta : Indeks. Pendidikan Nasional.

Stoner, J. P. (2000). Management 3 th ed. New Jersey: Prentice-Hall

Sudarmanto, R.G., (2009). Pengaruh Pembiayaan Pendidikan terhadap Kualitas Pelaksanaan Pembelajaran dan Prestasi Belajar Siswa Sekolah Menengah Kejuruan Ekonomi Di Bandar Lampung. Disertasi, Program Studi Pendidikan Ekonomi, Program Pascasarjana, Universitas Negeri Malang.

Syafaruddin, (2005), Manajemen Lembaga Pendidikan Islam, Jakarta: PT. Ciputat Press

Syarifudin. (2005). Administrasi Pembiayaan Pendidikan. Bandung: CV. Pustaka.

Tampubolon, D.P, (2013) Pembelajaran Bermutu di Perguruan Tinggi (Peningkatan Mutu Proses Pembelajaran dengan Pendekatan Manjaemen Mutu Terpadu). Jakarta: Forum Kerjasama Sembilan Universitas Kerjasama Indonesia-Kanada, Dirjendikti.

Tardif (1987). The penguin Macquarie dictionary of Australian education. Ringwood. Vivtoria. Penguin book Australia ltd.

Terry, G.R. dan Rue, Leslie W. (2005). Dasar - Dasar Manajemen. Jakarta: Bumi Aksara.

Undang-Undang Nomor 20 Tahun 2003 tentang Sistem Pendidikan Nasional 